\title{
RESEARCH ARTICLE Impact of sewage water irrigation on agricultural soil
}

\author{
Nageshwar Sahu1, L. K. Ramteke², Anup Kumar Singh1, Tapas Chowdhury1, Ravindra Soni1* \\ 1Department of Agricultural Microbiology, Indira Gandhi Krishi Vishwavidyalya, Raipur, Chhattisgarh state, India \\ 2Department of Soil Science and Agriculture Chemistry, Pt. SKS College of Agriculture and Research Station, Rajnandgaon, \\ Chhattisgarh state, India \\ *Corresponding author: Dr Ravindra Soni, Email: rs31693@gmail.com
} Ltd. a private company limited by shares organized and existing under the laws of Hungary, with its head office located at 33 Rákóczi, H-3950 Sárospatak, Hungary and company registration number: 05-09-033278.

How to cite: Sahu et al. "Impact of sewage water irrigation on agricultural soil" DRC Sustainable Future 2021, 2(2): 141-148, DOI: $10.37281 / \mathrm{DRCSF} / 2.2 .7$

\section{ABSTRACT}

The rapidly increasing population growth and the steady increase in water requirements for agricultural and industrial development have placed severe stress on the water resources available and the long term use of sewage water for irrigation highly affects soil properties. In this study soil samples were collected from a cauliflower field prior and after sewage water irrigation, and the impact of sewage water irrigation on physical, chemical, and biological properties of soil was compared. For this, tested were pH, Electrical Conductivity (EC), Organic Carbon, available Nitrogen, Phosphorus, Potassium, Calcium, Magnesium, Zinc, Iron, Copper, Manganese, and microbial activity. Soil microbial biomass carbon, basal soil respiration, total viable count of bacteria, coliform population, Pseudomonas species, and Azotobacter significantly increased after sewage water irrigation as compared to prior to irrigation. Nevertheless, the bulk density and Rhizobium species of the soil flooded with sewage water was decreased relative to the same characteristics prior to irrigation. Cauliflower yield was significantly increased when sewage water flooded field as compared to the tube well water flooded field (i.e., water delivered via an iron pipe). Escherichia coli contamination was greater in sewage water and groundwater that can pose health risks for the nearby communities, to farmers and consumer of farm products. Hence, the efficient use of sewage and municipal wastewater successfully increase water resource for irrigation and may help in expanding agricultural production. But excessive use of sewage water may also affect the soil flora and fertility.

Keywords: water quality, sewage water, agriculture, irrigation 


\section{Introduction}

Application of sewage and domestic wastewater to agricultural soil may increases physicochemical soil attributes, nutrient status, and yield (Singh et al., 2012; Bastida et al., 2019; Rezapour et al. 2021). Thus, it shows that improve in crop production with an increase in soil fertility status. The implementation of sewage water irrigation improves the yield of Rabi crops as opposed to well water irrigation; it also increases the overall soil content in $\mathrm{N}, \mathrm{P}, \mathrm{K}$, organic carbon, and microbial biomass carbon. Increase in soil microbial biomass carbon is likely to induce greater extent when wastewater is used for irrigation along with further rise in pollutant concentrations, which is expected to exert adverse effects on soil microbial populations. The effects of long-term wastewater application on soil include the increase of $\mathrm{pH}$, Electrical Conductivity (EC), heavy metals, and the change of soil biological characteristics which all constitute soil quality indicators (Angin et al., 2005). When they develop into a host plant, Plant Growth-Promoting Rhizobacteria (PGPR) represent a large population of soil microorganisms, which brings an increment in the development of the host plant. These Growth-Promoting Rhizobacteria (PGPR) offer expanded uptake, mobility, and advancement of supplements or nutrient in the plant (Cakmakci et al., 2006). Also, PGPR colonize plant roots that promote plant development and work as a biocontrol agent. Such microbes are found in rhizoplane and rhizosphere. Some PGPR are affected by irrigation with sewage water, which contains high concentrations of heavy metals.

A raw sewage water comprises pathogenic bacteria, virus, protozoa, and certain parasitic helminths that can cause possible health risks to humans, animals, and plants. In wastewater-saturated soil, the fingers of the workers or children would be contaminated, so that some pathogens could be transmitted to their mouths and ingested. Hence, the volume of soil casually ingested was estimated as high as $100 \mathrm{mg}$ per individual over one day of exposure (Haas et al., 1999; WHO, 2001). In addition, increased microbial activity may be attributed to the introduction of microbes by the drainage of wastewater, which carries large microbial loads, including complete types of bacteria that suggest fecal pollution. The species of bacteria may yield increased microbial respiration in soil, suggesting greater consistency of the soil (Raychaudhuri et al., 2014).

\section{Methods}

\section{Experimental sites}

A field experiment on cauliflower was conducted in Paneka village near Rajnandgaon City, Chhattisgarh (India). The town of Rajnandgaon is located at $21.10^{\circ} \mathrm{N}$ $81.03^{\circ}$ E. It has an average elevation of 307 meters above the mean sea level at the western part of Chhattisgarh plain. Industrial effluents drain from the industrial area of Rajnandgaon, whereas domestic wastewater originates from residential areas of Rajnandgaon. The field is located on the western side of the Pt. Shiv Kumar Shastri College of Agriculture and Research station in Rajnandgaon (CG) India.

\section{Physico-chemical properties of soil}

Soil $\mathrm{pH}$ was determined in 1:2 soil-water suspension potentiometrically, using a glass electrode and a $\mathrm{pH}$ meter (Piper, 1967). Soil EC was measured in 1:2 soilwater extract or supernatant liquid, after it was filtered, by means of an EC meter (Jackson, 1973). Walkley and Black method (1934) was used to determine the organic carbon content of soil samples. Nitrogen availability in soil samples was estimated by the alkaline permanganate method (Subbiah and Asija, 1956). Soil phosphorus content was determined by the Olsen method, i.e., Sodium Bicarbonate Extractable P method (Olsen et al., 1954). Potassium was estimated by flame photometer with the help of a standard curve developed by Jackson (1967). Exchangeable calcium and magnesium were evaluated by the Versanate titration method, in a neutral normal ammonium acetate extract (Cheng and Bray, 1951). Micronutrients were determined with the help of DTPA (pentetic acid or diethylenetriaminepentaacetic acid) extractant, using an AAS (atomic absorption spectrophotometer). This method was proposed by Lindsay and Norvell (1978).

\section{Microbial dynamics}

Microbiological studies were conducted using standard microbiological procedures for different groups of organisms (Boone and Castenholz 2001). The bacterial population was estimated by spread plate count technique, on nutrient agar media. Coliforms population was estimated by spread plate count technique, using MacConkey agar media. Rhizobium species population was assessed by spread plate count technique, using YEMA Media. Pseudomonas species population was estimated by spread plate count technique, using King's Medium B Base. Azotobacter species population was estimated by spread plate count technique on Jensen's Medium. Basal respiration of soil was determined by calculating levels of released $\mathrm{CO}_{2}$ (Anderson, 1982).

\section{Statistical analysis}

All data were analyzed through standard statistical procedures. The " $\mathrm{t}$ " test for the paired sample, mean, standard deviation, and coefficient of variation were used to determine the impact of sewage water irrigation on microbial diversity and cauliflower productivity. Statistical analyses were performed at $5 \%$ and/or $1 \%$ level of significance. 


\section{Results and discussion}

\section{Physico-chemical properties of sewage water irrigated soil}

The physico-chemical and microbiological properties of soil are significantly different prior and after sewage water irrigation (Figure 1)

\section{Soil bulk density}

The bulk density of soil irrigated with sewage water was significantly lower $(\mathrm{P}<0.01)$ than the bulk density of soil before irrigation. It was already reported that bulk density is affected by the organic carbon content of the soil (Céspedes-Pavret et al., 2017). Comparable outcomes were reported by Mathan (1994), Kharche et al., (2011), and Subramani et al. (2014).

\section{Soil pH}

The irrigation with sewage water is significant at $(\mathrm{P}<0.05)$ increased soil $\mathrm{pH}$, as compared to before irrigation. Comparative phenomena were experienced by Rusan (2007) and Rattan et al. (2005), who studied that the long-term effect of sewage and wastewater effluents on soil properties.

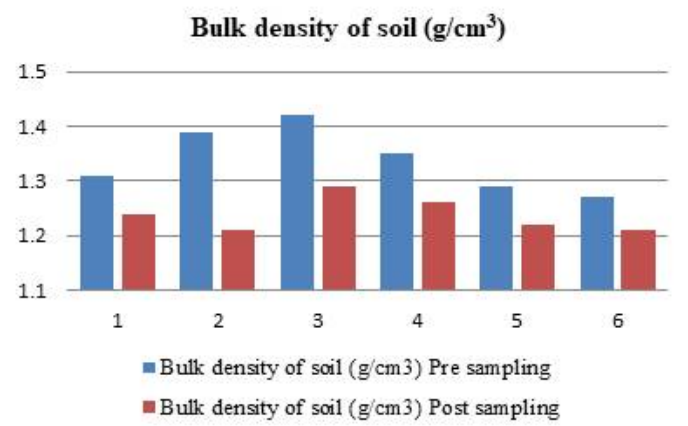

Effect of sewage water irrigation on soil EC

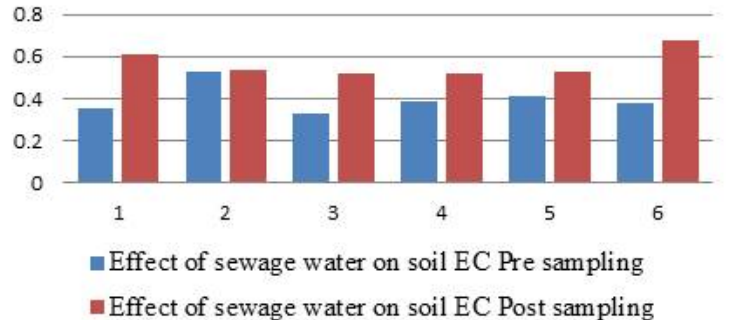

\section{Soil Electrical Conductivity (EC)}

Irrigation with sewage water significantly increased soil EC $(\mathrm{P}<0.05)$ relative to before irrigation. EC of soils increased after irrigation with wastewater because of the higher electrical conductivity of sewage water (Figure 1). This is in line with findings by Rusan et al. (2007) and Jahantigh (2008). The presence of high amounts of cations, for example, $\mathrm{Na}^{+}$and $\mathrm{K}^{+}$in wastewater promoted an increase in EC.

\section{Soil Organic Carbon (OC)}

The organic carbon in soils irrigated with sewage water is exceptionally significant at $(\mathrm{P}<0.01)$ when compared with organic carbon prior to irrigation. A greater quantity of organic carbon is present in sewage water because of municipal waste effluents. Increase $\mathrm{OC}$ was found in sewage water irrigated soil, which improved the infiltration rate, CEC, and diminished the bulk density. Each of these properties helped in improving the harvest profitability of the crop. Comparable outcomes were reported by various research groups (Datta et al., 2000; Yadav et al., 2002; Rattan et al., 2005; Gwenzi and Munondo, 2008; Kesba et al., 2010; Verma et al., 2013; Subramani et al., 2014).

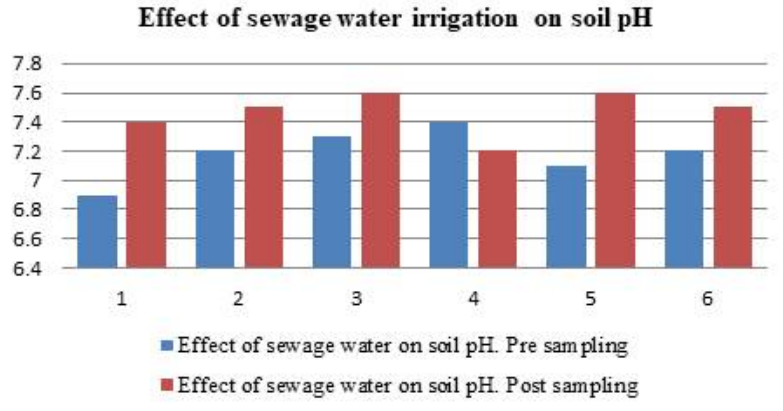

Effect of sewage water irrigation on soil OC \%

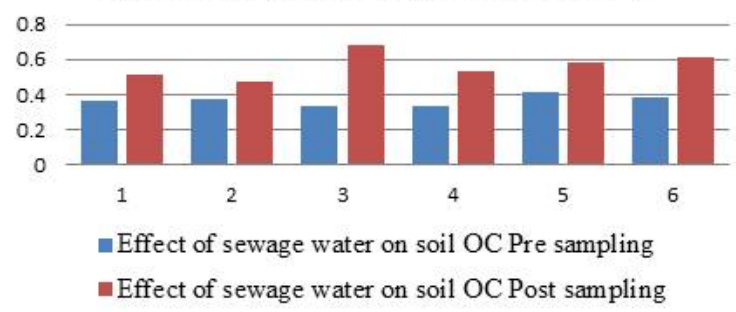

Figure 1. Effects of sewage water irrigation on the physico-chemical properties of soil. Soil samples from experimental fields were taken pre- and post-irrigation 


\section{Available macronutrients ( $N$, $P$, and $K$ ) in soil}

Nitrogen, phosphorus, and potassium contents were greater in soils irrigated with sewage water than in soils before irrigation. Given that sewage water contains more nitrogen than fountain water, soils flooded with sewage water have increased $\mathrm{N}$ substance content. In our examination, the P-value of available nitrogen in soils flooded with sewage water was significant $(\mathrm{P}<0.01)$. Similarly, the available $\mathrm{P}$ and $\mathrm{K}$ substances in the sewage water used for irrigation were significant at $(\mathrm{P}<0.05)$ and $(\mathrm{P}<0.05)$, respectively, when compared with the values before applying sewage water (Figure 2). Phosphorus and potassium were increased, because of the presence of more $\mathrm{P}$ and $\mathrm{K}$ substances in sewage water. Comparable outcomes were also reported previously by other researchers (Rattan et al., 2005; Gwenzi and Munondo, 2008).

\section{Available cations (Calcium and Magnesium)}

Cations, like $\mathrm{Ca}^{2+}$ and $\mathrm{Mg}^{2+}$ were more abundant in soils irrigated with sewage water as compared with not irrigated soil. The increase in calcium-containing substances in irrigated soils is a result of the high calcium content of sewage water, which enriches the available calcium in the soil. The P-value of available calcium in the soil flooded with sewage water was significant $(\mathrm{P}<0.05)$. Likewise, the available magnesium-containing substance of the sewage water applied soils was significant $(\mathrm{P}<0.05)$, as compared with soils before irrigation (Figure 2). Similarly with calcium, the magnesium content of soil increased because of higher magnesium substance concentrations in the sewage water utilized for irrigation (Kumar et al., 2011).

\section{Micronutrients extractable with DTPA $(\mathrm{Zn}, \mathrm{Cu}$, Fe, and Mn)}

DTPA-extractable microelements like $\mathrm{Zn}, \mathrm{Cu}, \mathrm{Fe}$, and $\mathrm{Mn}$ had higher concentrations in soils flooded with sewage water $(\mathrm{P}<0.01), \quad(\mathrm{P}<0.05), \quad(\mathrm{P}<0.01)$, and $(\mathrm{P}<0.01)$, respectively, relative to not irrigated soils. Higher concentrations of micronutrients in soil are toxic for plant development. Sewage water contained all the listed DTPA-extractable microelements in higher concentrations than well water (Figure 2), as micronutrients are more abundant in sewage water. Comparable outcomes were accounted for by Patel et al. (2004), Oman et al. (2010), Prakash et al. (2010), Kharche et al. (2011), and Zan et al. (2013).

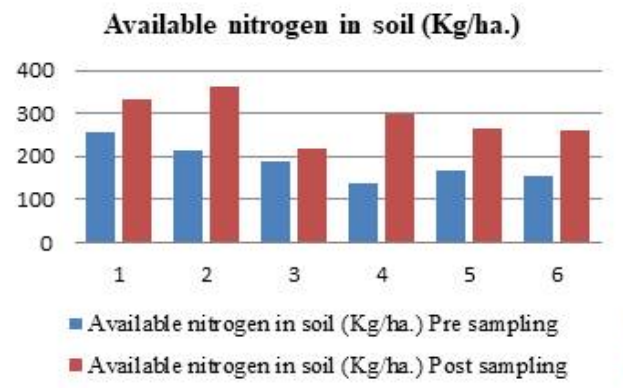

Available Calcium in soil (Kg/ha.)

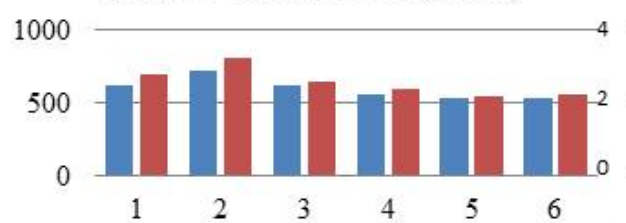

m Available Calcium in soil ( $\mathrm{Kg} / \mathrm{ha}$.) Pre sampling

m Available Calcium in soil ( $\mathrm{Kg} / \mathrm{ha}$.) Post sampling

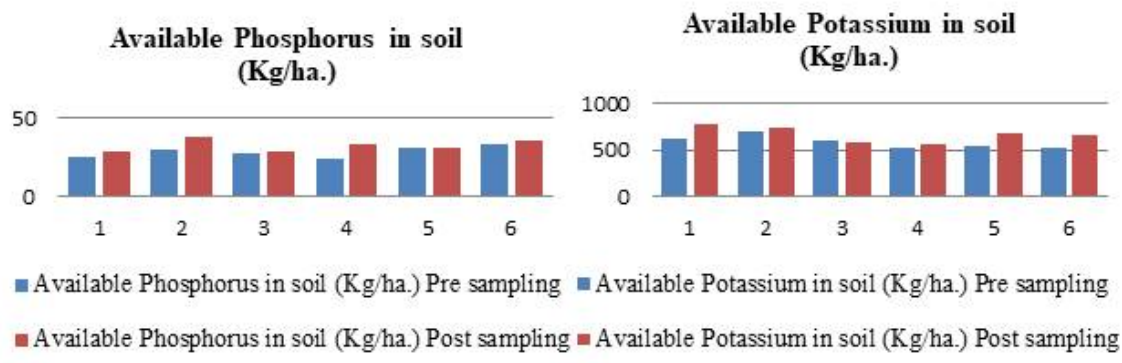

Zink concentration in soil (ppm)

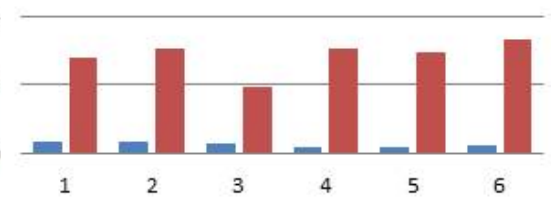

Zink concentration in soil (ppm) Pre sampling - Zink concentration in soil (ppm) Post sampling

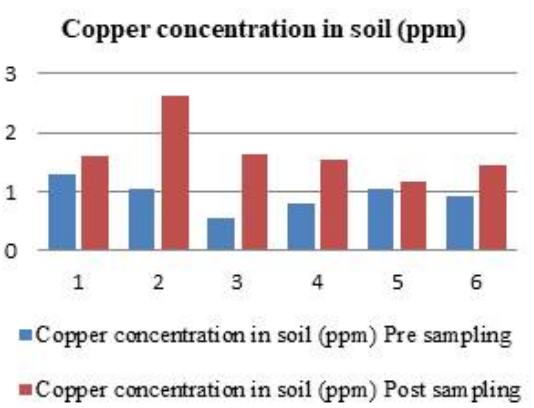

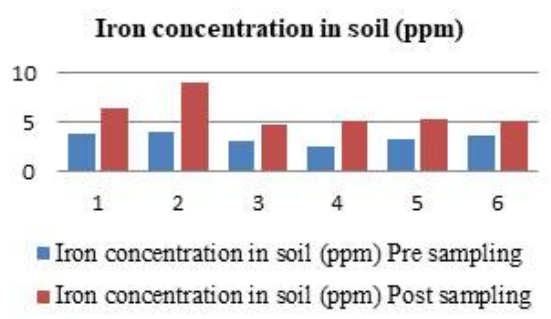

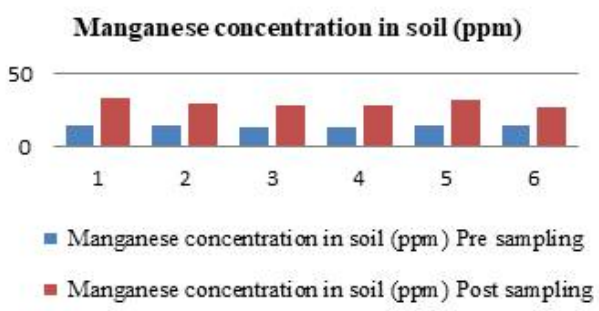

Figure 2. Effects of sewage water irrigation on available nutrients in soil. Soil samples from experimental fields were taken 


\section{Microbial properties of sewage water and tube- well water}

Escherichia coli population is greater compared to the standard limit given by BIS (1995) and WHO (2004). Clark and co-workers (2003) believe that the high concentration of natural substances and create ideal conditions for growth and bacterial development. Continuous use of Escherichia coli contaminated water for drinking or irrigation purposes may pose health risks, for example, urinary tract infections, respiratory diseases, abscesses, and skin-twisted diseases. These are threats to neighborhood residents of this locality, particularly youngsters and children.

\section{Effect on biochemical properties of soil Microbial Biomass Carbon (MBC)}

Microbial Biomass Carbon is significantly expanded at $(\mathrm{P}<0.01)$ in sewage water flooded soil, as compared to $\mathrm{MBC}$ values recorded prior to irrigation. This is a source or sink of accessible nutrients and it assumes a basic job in nutrients transformation in earthly environments (Singh et al., 1989). The quantity of the microbial biomass may be affected by organic matter added to the soil; soil microbial activity completely influenced by the soil environmental system (Smith et al., 1993). In our current examination, $\mathrm{MBC}$ was estimated higher in the soils flooded with sewage water than in soils flooded with non-sewage water. Greater MBC in sewage-treated soil was higher in organic substance, owing to the higher microbial mass. MCB values ranged from $165.5 \mathrm{mg} \mathrm{kg}^{-1}$ (before sewage water irrigation) to $213.66 \mathrm{mg} \mathrm{kg}^{-1}$ (field irrigated with sewage water). The MBC was found more abundant in soils flooded with wastewater, relative to MCB prior to sewage water irrigation. This outcome was common for bacterial population in the soil compartment rich in organic matter (Palese et al., 2009). The MBC diminished with increasing soil depth. Comparative outcomes were accounted for by Antil et al. (2004), Zan et al. (2013), Kharche et al. (2011), Oman et al. (2010), Rattan et al. (2001), and Datta et al. (2000)

\section{Basal soil respiration}

Soil basal respiration is the balanced rate of respiration in soil, which starts from the mineralization of organic matter (Pell et al., 2006), and is assessed either based on $\mathrm{CO}_{2}$ enhancement or $\mathrm{O}_{2}$ uptake (Dilly and Zyakun, 2008). Soil basal respiration is significantly increased $(\mathrm{P}<0.01)$ soil flooded with sewage water relative to levels prior to water irrigation. The mean estimation of the soil basal respiration ranged between 0.513 (Pre sampling) and 0.692 (Post sampling) $\mathrm{mg} \mathrm{C}-\mathrm{CO}_{2} / \mathrm{h} / 100 \mathrm{~g}$ of soil. Enhanced basal respiration of soil was assigned to the presence of organic carbon in sewage water irrigated soil. Similar results were reported by Cacio Luiz Boechat et al. (2012). Reports by Cleveland and co-workers (2007) demonstrated that the expanded reaction in soil microbial action was related to easily accessible $\mathrm{C}$ sources in the soil.

\section{Dynamics of microbial population Total viable count of bacteria}

In soil irrigated with sewage, the number of microorganisms increased significantly $(\mathrm{P}<0.01)$ as compared with prior to irrigation. The mean value of total viable bacteria in sewage water-irrigated soil was 8.38 and 7.90 before sewage water irrigation (Figure 3). The microbial population in sewage-flooded soils was more significant for bacteria, fungi, and actinomycetes as compared to samples taken prior to irrigation (Kharche et al., 2011). This might be a result of suspended organic material added to the soil via sewage, which works as good medium sustaining microbial population. Comparative outcomes were disclosed by Seaker and Sopper (1988) and Joshi and Yadav (2003).

\section{Coliform population}

Wastewaters describe as the fundamental wellspring of water contamination in numerous countries worldwide, including Egypt (Yehia and Sabae, 2011), Poland (Niewolak, 2000), Nigeria (Akaninwor et al., 2007), and Brazil (Gunkel et al., 2007). Several research groups have inspected the vehicle of microorganisms in the soil subsequently to applying sewage water (Schaub and Sorber, 1977; Smith et al., 1985). Yongabi and coworkers (2011) studied the effects on soil of abundant microorganisms present in contaminated water. Presence of fecal coliform microbes demonstrates that waterways are contaminated by sewage and other pathogenic microbes. Irrigation with sewage water significantly increased $(\mathrm{P}<0.01)$ the fecal coliform population of soil as compared to before irrigation. Soils become highly polluted after long-term irrigation with sewage water (Figure 3). Some strains of Escherichia coli cause sickness to humans, including fever, abdominal pain, diarrhea, and vomiting. The Escherichia coli 0157:H7 strain delivers toxins known as Shiga. These belong to the most aggressive poisonous ingredients, which can cause intestinal contamination (Yvette Brazier, 2017).

\section{PGPR population}

Figure 3 reveals the effects of PGPRs population density for microbes collected from soils irrigated with effluent water of wastewater treatment plants. One can notice that the number of advantageous micro fauna was significantly diminished, like the Rhizobium population of soil, as compared with their presence prior to sewage water irrigation. Heavy metal contaminants like $\mathrm{Ag}, \mathrm{Hg}$, $\mathrm{Pb}, \mathrm{Zn}, \mathrm{As}, \mathrm{Cd}, \mathrm{Cr}, \mathrm{Na}, \mathrm{K}$, and $\mathrm{Cu}$ are harmful to PGPRs, and other beneficial microorganisms present in the soil. Hence, the presence of $\mathrm{Ag}$ nanoparticles 

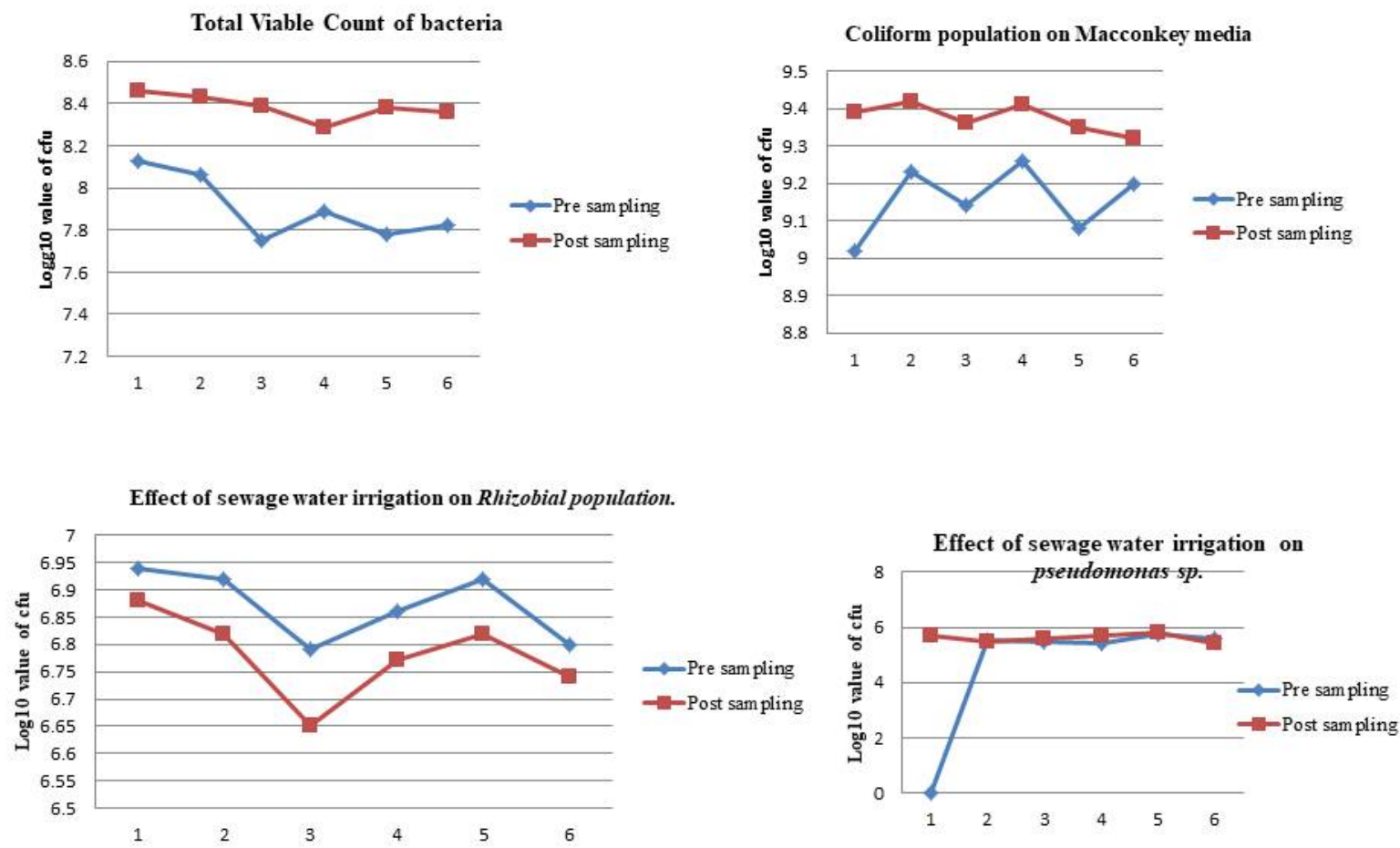

Figure 3. Effects of sewage water irrigation on soil bacterial population. Soil samples from experimental fields were taken pre- and post-irrigation

decreased the CFU of all PGPR organisms. This conclusion agrees with that reported by Revathi et al. (2011).

\section{Rhizobial population}

Irrigation with sewage water significantly depleted in $(\mathrm{P}<0.01)$ Rhizobium population of soils, because of the high concentration of heavy metals in sewage water (Figure 3). Comparative outcomes were found by Castro et al. (1997), Chaudhary et al. (2004), Chaudri et al. (2000), Lakzian et al. (2002), and Smith (1997), who all studied the effects of heavy metals on growth, development, morphology, and physiology of different strains of Rhizobium leguminosarum. Continuous introduction of heavy metals changes the suitable bacterial cells into a non-reasonable structure (Paton et al., 1997; Hirsch et al., 1993). Decrease in bacterial cells of Rhizobium species were accounted for by the augmenting concentration of heavy metals, such as $\mathrm{Cu}$, $\mathrm{Zn}$, and $\mathrm{Pb}$, either on their own or in mixtures (Stan et al., 2011).

\section{Pseudomonads}

A few types of Pseudomonas species found in the environment, which act as plant growth promoters (Sullivan et al., 1992), plant pathogenic (Schroth et al., 1991), and xenobiotic degraders (Ridgway et al., 1990). Results indicate that urban wastewater contains high amounts of microorganisms and the endurance capability of different PGPRs to grow heavy metals is different. Pseudomonas species can grow better and have the most extreme CFU. In available city wastewater, a noticeable increment in CFU of Pseudomonas species may indicate the presence of organic matter in the urban wastewater, which filled as $\mathrm{C} / \mathrm{N}$ source for the PGPR. Comparable results were disclosed by Yongabi et al. (2011).

\section{Azotobacter species}

Quantities of Azotobacter in sewage irrigated soils increased relative to soils prior to irrigation, which was significant based on statistical analysis $(\mathrm{P}<0.05)$. The number of free live nitrogen-fixing microorganisms first increased and diminished after sewage water irrigation (Shang et al., 2007). Increase of Azotobacter population in sewage water irrigated soil was a consequence of organic matter abundance in sewage water. This line corresponds to a report by Zhang et al. (2007).

\section{Cauliflower yield}

Irrigation with sewage water significantly increased at statistical level of $(\mathrm{P}<0.01)$ yield of cauliflower, as compared to tube-well water irrigation (Figure 4). This is a result of the higher nutrient concentration found in sewage water. Similar findings were reported by Sheikh and co-workers (2012). 


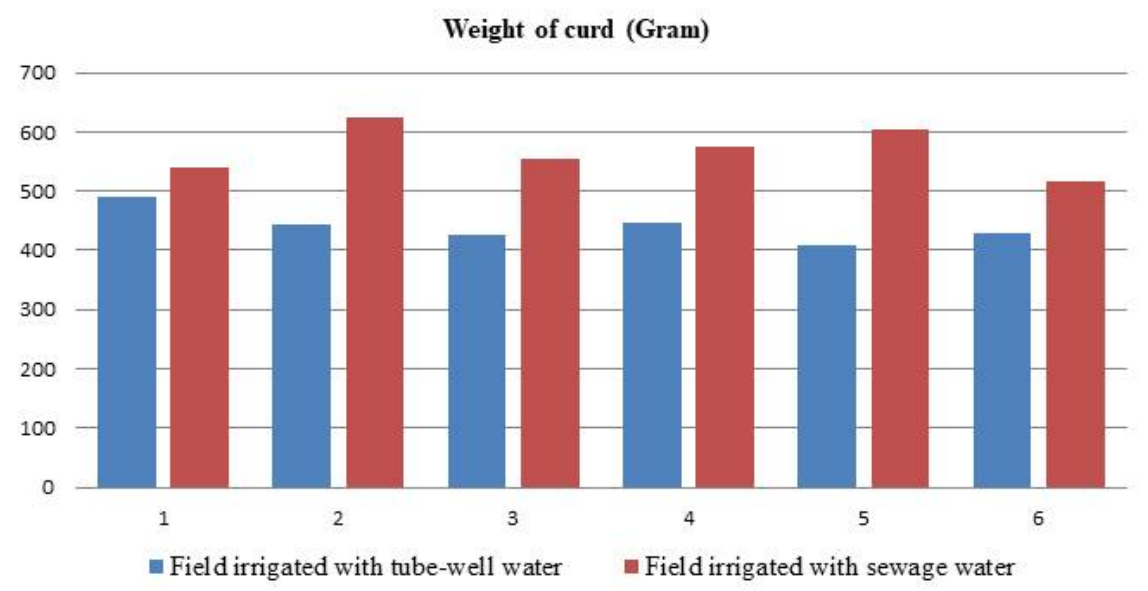

Figure 4: Effect of sewage water irrigation on cauliflower yield

\section{Conclusions}

Our results revealed that use of sewage water for irrigation improved the physical, chemical, biological properties of the soil. Rhizobium species construed an exception, as the quantity of bacteria decreased after irrigation. All heavy metals, including $\mathrm{Zn}, \mathrm{Mn}, \mathrm{Fe}$ and $\mathrm{Cu}$ were assessed in high concentration in the irrigated land, and these metals harmed Rhizobium species present in the soil. Outcomes of site investigation, where sewage and municipal wastewater have been utilized over a long period accounted for the increase of organic carbon and nutrients in the soil. We have used this water as a form of fertilizer, owing to their high concentration levels of N, P, K, and high micro-nutrients. Hence, the potential use of sewage and municipal wastewater can successfully increase water resource for irrigation and may help in expanding agricultural production. Nevertheless, it may also result in an adverse effect on crop and may harm beneficial microbes because of their high level of toxic heavy metals. When sewage and municipal wastewater are used in agriculture, certain chemicals become virulent Escherichia coli may cause hazards to human health via exposure from different sources. Therefore, one needs to manage the irrigation of lands with sewage and municipal wastewaters, while also monitoring soil fertility and soil quality parameters. By using this procedure, one can secure prosperous, safe, long-term use of wastewater water irrigation. Also, sewage water can be mixed with groundwater as an alternate way of irrigation.

\section{References}

Angin, I., Yaganoglu, A.V., Turan, M. (2005). "Effects of long-term wastewater irrigation on soil properties." J. Sustainable Agriculture 26 (3), 31-42.
Bastida, F.; Jehmlich, N.; Martínez-Navarro, J.; Bayona, V.; García, C.; Moreno, J.L. (2019) "The effects of struvite and sewage sludge on plant yield and the microbial community of a semiarid Mediterranean soil". Geoderma, 337, 1051-1057.

Boone D R, R W. Castenholz (2001) "Bergey's Manual ${ }^{\circledR}$ of Systematic Bacteriology". Vol 1, Springer, New York, NY. https://doi.org/ 10.1007/978-0-387-21609-6

Bhise, P.M., Challa, O., Venugopalan, M.V. (2007). "Effect of waste water irrigation on soil properties under different land use systems." J. Indian Society Soil Science 55 (3), 254-258.

Borthakur, O. (2011). "Evaluation of degradability of different herbicides in inceptisol in terms of microbiological and biochemical properties of rice rhizosphere (Doctoral Dissertation, Indira Gandhi Krishi Vishwavidyalaya, Raipur (CG).

Cakmakçi, R., Dönmez, F., Aydın, A., Şahin, F. (2006). "Growth promotion of plants by plant growth-promoting rhizobacteria under greenhouse and two different field soil conditions." Soil Biology Biochem. 38 (6), 1482-1487.

Céspedes-Payret, C., Bazzoni, B., Gutiérrez, O. et al. (2017). "Soil Organic Carbon vs. Bulk Density Following Temperate Grassland Afforestation". Environ. Process. 4, 75-92 https://doi.org/10.1007/ s40710-016-0197-4

Chen, L., Feng, Q., Li, C., Wei, Y., Zhao, Y., Feng, Y., Li, H. (2017). "Impacts of aquaculture wastewater irrigation on soil microbial functional diversity and 
community structure in arid regions." Scientific Reports 7 (1), 1-10.

Chhonkar, P.K., Datta, S.P., Joshi, H.C., Pathak, H. (2000). "Impact of industrial effluents on soil health and agriculture-Indian experience: Part I-Distillery and paper mill effluents."

De-lan, X.U., Cui-ying, Z.H.A.N.G., Shu-ming, Q.U., Xu, M.A., Ming-xia, G.A.O. (2013). "Characterization of microorganisms in the soils with sewage irrigations." African J. Microbiology Research 6 (44), 7168-7175.

Deshmukh, S.K., Singh, A.K., Datta, S.P., Annapurna, K. (2011). "Impact of long-term wastewater application on microbiological properties of vadose zone." Environm. Monitoring Assessment 175 (1-4), 601-612.

Friedel, J.K., Langer, T., Siebe, C., Stahr, K. (2000). "Effects of long-term waste water irrigation on soil organic matter, soil microbial biomass and its activities in central Mexico." Biology Fertility of Soils 31 (5), 414-421.

Gopalakrishnan, S., Sathya, A., Vijayabharathi, R., Varshney, R.K., Gowda, C.L., Krishnamurthy, L. (2015). "Plant growth promoting rhizobia: challenges and opportunities." Biotech 5 (4), 355-377.

Hidri, Y., Fourti, O., Eturki, S., Jedidi, N., Charef, A., Hassen, A. (2014). "Effects of 15-year application of municipal wastewater on microbial biomass, fecal pollution indicators, and heavy metals in a Tunisian calcareous soil.” J. Soils Sediments 14 (1), 155-163.

Khan, N., Bano, A. (2016). "Role of plant growth promoting rhizobacteria and Ag-nano particle in the bioremediation of heavy metals and maize growth under municipal wastewater irrigation." Int. J. Phytoremediation 18 (3), 211-221.

Kiziloglu, F.M., Turan, M., Sahin, U., Angin, I., Anapali, O., Okuroglu, M. (2007). "Effects of wastewater irrigation on soil and cabbage-plant (brassica olerecea var. capitate cv. yalova-1) chemical properties.” J. Plant Nutrition Soil Science 170 (1), 166-172.

Kumawat, S., Yadav, B., Majumdar, S. (2017). "Effect of Municipal Sewage on Soil Biological Properties in the Vicinity of Jaipur City of Eastern Rajasthan" India. Int. J. Curr. Microbiol. App. Sci 6 (8), 1683-1689.

Malla, R., Totawat, K.L. (2006). "Effect of municipal sewage on soil properties and chemical build-up in vegetable crops grown on Haplustepts of sub-humid southern plains of Rajasthan." J. Indian Society Soil Science 54 (2), 226-231.

Malla, R., Mori, K., Totawat, K.L. (2007). "Effect of municipal sewage on chemical build-up in soils and vegetables." Water Science and Technology: Water Supply 7 (4), 79-85.

Rattan, R.K., Datta, S.P., Chhonkar, P.K., Suribabu, K., Singh, A.K. (2005). "Long-term impact ofirrigation with sewage effluents on heavy metal content in soils, crops and groundwater - a case study." Agriculture, Ecosystems \& Environment 109 (3-4), 310-322.

Rezapour, S.; Nouri, A.; Jalil, H.M.; Hawkins, S.A.; Lukas, S.B. (2021) "Influence of Treated Wastewater Irrigation on Soil Nutritional-Chemical Attributes Using Soil Quality Index." Sustainability, 13, 1952. https:// doi.org/10.3390/su13041952

Singh, P.; Deshbhratar, P.; Ramteke, D. (2012) "Effects of sewage wastewater irrigation on soil properties, crop yield and environment". Agric. Water Manag., 103, 100104.

Vander Zaag, A.C., Campbell, K.J., Jamieson, R.C., Sinclair, A.C., Hynes, L.G. (2010). "Survival of Escherichia coli in agricultural soil and presence in tile drainage and shallow groundwater." Canadian J. Soil Science 90 (3), 495-505.

Zhang, J., Zhang, H.W., Su, Z.C., Li, X.Y., Zhang, C.G. (2006). "The effect of long-term organic wastewater irrigation on the soil nitrogen-fixing bacteria population." J. Agro-Environment Science 26 (2), 662-666. 